\title{
Response of Guava Transplants to Soil and Foliar Spray with Some Bio-Stimulants
}

\author{
M.A. Khamis, M.M., Sharaf, Kh. A. Bakry and A. S. Abd \\ El- Moaty \\ Horticulture Department, Faculty of Agriculture, Benha \\ University, Benha, Egypt.
}

\begin{abstract}
THIS research aimed to study the effect of some bio-stimulants on growth and nutritional status of guava transplants in order to reduce the mineral fertilization during seasons of 2011 and 2012. Results revealed that all treatments significantly increased vegetative growth i.e., (stem height and diameter, number of shoots, number of leaves and leaf area) in both seasons. Results, also, indicated that leaf photosynthetic pigments content (chlorophyll a, b and carotenoids) were increased as well as leaf mineral contents $(\mathrm{N}, \mathrm{P}, \mathrm{K}, \mathrm{Ca}, \mathrm{Mg}, \mathrm{Fe}$, $\mathrm{Mn}$ and $\mathrm{Zn}$ ) were improved by the different treatments. Therefore, it could be concluded that, all investigated bio - stimulants improve growth and nutritional status especially foliar application of $20 \mathrm{~g}$ Kotengin $+40 \mathrm{~g}$ phosphorine $+40 \mathrm{~g}$ Rhizobacterin/ plant $+20 \mathrm{~g}$ $\mathrm{K}_{2} \mathrm{SO}_{4} /$ plant followed by foliar application of $20 \mathrm{~g}$ Kotengin $+40 \mathrm{~g}$ Rhizobacterin per plant + PK applied of control.
\end{abstract}

The guava "Psidium guajava L." is believed to be native to the areas between Mexico and Peru. It has spread to all over the tropical and subtropical countries, Chandler (1958). Guava fruits are the cheapest and richest source in vitamin "C", as well as it contains small amounts of vitamin "A", "B", carbohydrates, oils and proteins, Godeston and Chain (1946).

Guava trees occupy 38873 feddans, which in turn produced about 314438 metric tons fruits. (Statistics of Ministry of Agriculture, A. R. E. 2012).

Bio-fertilizers are important for plant production as they play an vital role in increasing vegetative growth, yield and fruit quality (Haggag and Azzazy, 1996) on mango seedling (Soliman, 2001) on guava and banana plants (Abd-Rabou, 2006) on avocado plants, (Ahmed et al., 1999 and Osman et al., 2010) on olive plants, (Chokha et al., 2000, El-Geuoshy, 2011 and Bakry et al., 2013) on sweet orange. Shaban and Mohsen (2009) also showed that, all bio-fertilizers were effective in improving vegetative growth and nutritional status of sweet orang transplants. Bio-fertilization is biological preparations containing primarily patent strains of micro- organisms in sufficient populations. The multi - strain bio-fertilizers might contain different strains of symbiotic as sociative phos phate solubilizing micro-organisms, silicate dissolving micro- organisms, blue green algae and VAM (Saber, 1993). They proved to eliminate the use of pesticides 
sometimes and rebalance the ratio between plant nutrients in soils. It is worthy to state that, bio-fertilizers do not replace mineral fertilizers, but significantly reduce their rate of applications. Bio-fertilizers are very safe for human, animal and environment. Since, they reduce at the lower extent the great environ mental pollution. Phosphorine is a bio-fertilizer product containing active microorganisms hydrolyzing the insoluble phosphate into soluble one under high soil $\mathrm{pH}$ and greater percentage of calcium carbonate, consequently partially overcomes the phosphate blocking and/or unavailability. In addition, Rhizobacterin as new bio-fertilizers have greater amount of symbiotic bacteria and non symbiotic bacteria responsible for nitrogen fixation. Application of both achieved the following advantages:

1-Reduce plant requirements of nitrogen by $25 \%$; 2- Improve the availability of various nutrients for plant absorption; 3-Increase the resistance of plants to root disease; 4-Reduce the environmental pollution induced by the application of chemical fertilizers; 5-Improve the productivity of the trees (Ishac, 1989).

Bio-fertilizers are now available commercially. Specific strains are used as biological fertilizers, for nitrogen, phosphorus and silicate dissolving such as $\mathrm{N}$ fixing bacteria and yeasts. The use of these materials encourages yield and keeps the environment clean.

The present study aimed to throw some light on the beneficial effect of replacing mineral $\mathrm{N}, \mathrm{P}$ and $\mathrm{K}$ soil application with foliar application with some bio-fertilizers namely Novatrene and Biomagic on growth and nutritional status of guava transplants.

\section{Material and Methods}

The present investigation was carried out during two successive seasons of (2011 and 2012) at nursery of Hort., Fac. of Agric., Benha Univ., Egypt. A uniform and healthy one-year- old seedlings of guava "Psidium guajava, L." were carefully selected and used as plant material. In both seasons of study and during the first week of February, those seedlings were transplanted individually each in a plastic pot of $35 \mathrm{~cm}$ in diameter that previously had been filled with specific weight of growing medium consisting of clay and sand at equal proportion $(\mathrm{V}: \mathrm{V})$. Mechanical and chemical analysis of growing media were done as shown in Table (1 a\&b) according to the methods described by Jackson, (1967) and Israelsen \& Hansen (1962).

TABLE (1-a). Physical properties of soil media used for growing guava seedlings (\%).

\begin{tabular}{|l|c|c|}
\hline Partial distribution & \multicolumn{2}{|c|}{} \\
\hline Total sand & Silt & Clay \\
\hline $65.00 \%$ & $10.00 \%$ & $25 \%$ \\
\hline
\end{tabular}

Egypt. J. Hort. Vol. 42, No.1 (2015) 
TABLE (1-b). Chemical properties of soil media used for growing guava seedlings.

\begin{tabular}{|c|c|c|c|c|c|c|c|c|c|c|}
\hline \multicolumn{4}{|c|}{ Soluble cations mg/L } & \multicolumn{4}{|c|}{ Soluble anions mg/L } & \multirow{2}{*}{$\mathrm{CaCO}_{3}$} & & \multirow[b]{2}{*}{ EC } \\
\hline $\mathbf{M g}^{++}$ & $\mathbf{C a}^{++}$ & $\mathbf{K}^{+}$ & $\mathrm{Na}^{+}$ & $\mathrm{HCO3}$ & $\mathrm{CO3}^{-}$ & SO4-- & $\mathrm{Cl}^{-}$ & & & \\
\hline 2.10 & 8.80 & 0.60 & 7.70 & 3.00 & - & 9.20 & 6.90 & 1.30 & 7.72 & 1.90 \\
\hline
\end{tabular}

The bio-fertilizers (BF) used in this study were produced by soil microbiology unit, Desert Res. Center. This experiment involved eight treatments:

- Mineral NPK fertilization program as control was annually added at the rate of $40 \mathrm{~g}$ ammonium sulphate, $40 \mathrm{~g}$ superphosphate and $20 \mathrm{~g}$ potas sium sulphate per pot (plant). Whereas, the corresponding amount of each NPK fertilizer was fractionized into five equal doses to be soil applied monthly from mid March till mid July during both season plus water spray $\left(50 \mathrm{~cm}^{3} /\right.$ transplant).

- Foliar spray of urea at $1 \%+$ Orthophosphoric acid at 100 ppm $\mathrm{P}_{2} \mathrm{O}_{5}+\mathrm{K}_{2} \mathrm{SO}_{4}$ at $1 \%\left(50 \mathrm{~cm}^{3} /\right.$ transplant $)$.

- Foliar spray of diluted Novatrene 1.0 conc.: 150 water (v:v) $\left(50 \mathrm{~cm}^{3} /\right.$ transplant).

- Foliar spray of Biomagic at $7.5 \mathrm{~g} / \mathrm{L}\left(50 \mathrm{~cm}^{3} /\right.$ transplant $)$.

- Foliar spray of diluted Novatrene solution (1.0: $150 \mathrm{v}: \mathrm{v})$ at the rate of $50 \mathrm{~cm}^{3} /$ plant plus soil application of Kotengin at $20 \mathrm{~g} /$ plant + phosphorine at $40 \mathrm{~g} /$ plant + Rhizobacterin at $40 \mathrm{~g} /$ plant $+\mathrm{K}_{2} \mathrm{SO}_{4}$ at $20 \mathrm{~g} /$ plant .

- Foliar spray of diluted Novatrene solution (1.0: $150 \mathrm{v}: \mathrm{v})$ at the rate of $50 \mathrm{~cm}^{3} /$ plant plus soil application of Kotengin at $20 \mathrm{~g} /$ plant + one liter Biovit (prepared by dissolving one liter of commercial Biovit in 50 liter water) + $\mathrm{K}_{2} \mathrm{SO}_{4}$ at $20 \mathrm{~g} /$ plant.

- Foliar spray of diluted Biomagic $\left(7.5 \mathrm{~g} / \mathrm{L}\right.$ water) at the rate of $50 \mathrm{~cm}^{3} / \mathrm{plant}$ plus soil application of Kotengin at $20 \mathrm{~g} /$ plant + phos phorine at $40 \mathrm{~g} /$ plant + Rhizobacterin at $40 \mathrm{~g} /$ plant $+\mathrm{K}_{2} \mathrm{SO}_{4}$ at $20 \mathrm{~g} /$ plant.

- Foliar spray of diluted Biomagic $(7.5 \mathrm{~g} / \mathrm{L}$ water) at the rate of $50 \mathrm{~cm} .3 /$ plant plus soil application of Kotengin at $20 \mathrm{~g} /$ plant + one liter Biovit (prepared by dissolving one liter of commercial Biovit in 50 liter water) $+\mathrm{K}_{2} \mathrm{SO}_{4}$ at 20 g/ plant.

Bio-fertilizers (Kotengin, Biomagic, Phosphorine, Rhizobacterin and Biovit each was applied once/ year in March. Foliar application with urea, $\mathrm{H}_{3} \mathrm{PO}_{4}$, $\mathrm{K}_{2} \mathrm{SO}_{4}$, Novatrene and Biomagic solutions were periodically sprayed 5 times at one month interval starting from mid March till mid July every season.

The response of guava seedlings to differential treatments were investigated throw determining of the following measurements:

Vegetative growth measurements

At the last week of October during both seasons, as the experiment was ended, the effect of different treatments on some vegetative growth measurements were evaluated i.e. increment percentage in stem height, stem 
diameter, average number of shoots/ plant, average number of leaves/ plant and average leaf area $\left(\mathrm{cm}^{2}\right)$.

\section{Chemical analysis}

Photosynthetic pigments (chlorophyll a, b and carotenoids) and leaf mineral content (N, P, K, Ca, Mg, Fe, Mn and Zn) were determined as described by A. O. A. C. (1990).

\section{Statistical analysis}

Data were subjected to analys is of variance according to (Snedecor and Cochran, 1977). In addition, significant differences among means were differentiated according to the Duncan's, multiple test range (Duncan, 1955).

\section{Results and Discussion}

\section{Vegetative growth measurements}

Increment percentage in both stem height and diameter, average number of shoots/ plant, average number of leaves and leaf area were studied as influenced by the differential bio-fertilizers (Kotengin, Biomagic, Phosphorine, Rhizobacterin, Biovit and Novatrien) treatments during 2011\& 2012 seasons are presented in Table 2 .

As shown from Table 2 all investigated bio- fertilizer treatments increased significantly the abovementioned five growth parameters as compared with control. However, such response varied obviously from one treatment to another, in spite of all growth parameters followed in most cases, the same trend during both experimental seasons. Anyhow, foliar spray of diluted Biomagic (7.5g / water) at the rate of $50 \mathrm{~cm}^{3} /$ plant plus soil application of Kotengin at $20 \mathrm{~g} / \mathrm{plant}$ + one liter Biovit $+\mathrm{K}_{2} \mathrm{SO}_{4}$ at $20 \mathrm{~g} /$ plant $\left(8^{\text {th }}\right.$ treatment $)$ was the most effective and ranked statistically $1^{\text {st }}$, whereas it resulted in the greatest average stem (height \& thickness), number of shoots pertransplant, number of leaves per shoot and average leaf area during the two experimental seasons. On the contrary, the least values of all investigated growth parameters were significantly exhibited by (control). In addition, other treatments were in between the aforesaid two extremes.

This result goes in line with the findings of Izquierdo et al. (1993) and Chokha et al. (2000) on growth measurements of bio-fertilized Volkamer lemon and Mosambi sweet orange, respectively as they gave support to the obtained result particularly as the benefit effect of Biomagic application was concerned. Also, this result goes partially in line with those found by Bakry et al. (2013) on Washington navel orange trees and Khamis et al. (2012) on sweet orange stated that, the addition of bio-fertilizers increased vegetative growth measurements.

On the other hand, the noticeable positive effect of six investigated bio fertilizers may be attributed to the improvement in soil physical and chemical properties induced by the additional $\mathrm{N}$ source like as Kotengin, Biomagic, Egypt. J. Hort. Vol. 42, No.1 (2015) 
Phosphorine, Rhizobacterin, Biovit and Hummer which reflected positively on various nutrient absorption.

TABLE 2. Effect of mineral NPK fertilizers and their combinations with some bio fertilizers soil and foliar spray applied on vegetative growth of guava transplants during $2011 \& 2012$ seasons.

\begin{tabular}{|c|c|c|c|c|c|c|c|c|c|c|}
\hline \multirow{2}{*}{ Treat } & \multicolumn{2}{|c|}{$\begin{array}{l}\text { Increment (\%) } \\
\text { in stem height }\end{array}$} & \multicolumn{2}{|c|}{$\begin{array}{l}\text { Increment (\%) } \\
\text { in Stem diameter }\end{array}$} & \multicolumn{2}{|c|}{$\begin{array}{l}\text { No. of Shoots } \\
\text { per transplant }\end{array}$} & \multicolumn{2}{|c|}{$\begin{array}{l}\text { No. of leaves } \\
\text { per transplant }\end{array}$} & \multicolumn{2}{|c|}{$\begin{array}{c}\text { Leaf area } \\
\left(\mathrm{cm}^{2}\right)\end{array}$} \\
\hline & $\begin{array}{c}1^{s t} \\
\text { season }\end{array}$ & $\begin{array}{c}2^{n d} \\
\text { season }\end{array}$ & $\begin{array}{c}1^{s t} \\
\text { season } \\
\end{array}$ & $\begin{array}{c}2^{\text {nd }} \\
\text { season }\end{array}$ & $\begin{array}{c}1^{\text {st }} \\
\text { season }\end{array}$ & $\begin{array}{c}2^{n d} \\
\text { season }\end{array}$ & \begin{tabular}{|c|}
$1^{s t}$ \\
season \\
\end{tabular} & $\begin{array}{c}2^{\text {nd }} \\
\text { season } \\
\end{array}$ & $\begin{array}{c}1^{\text {st }} \\
\text { season } \\
\end{array}$ & $\begin{array}{c}2^{n d} \\
\text { season }\end{array}$ \\
\hline 1 & $25.00 \mathrm{H}$ & $23.06 \mathrm{G}$ & $16.99 \mathrm{H}$ & $17.00 \mathrm{H}$ & $1.00 \mathrm{E}$ & $1.00 \mathrm{G}$ & $50.00 \mathrm{G}$ & $52.06 \mathrm{E}$ & $22.50 \mathrm{H}$ & $21.71 \mathrm{H}$ \\
\hline 2 & $47.05 \mathrm{G}$ & $47.52 \mathrm{~F}$ & $27.61 \mathrm{G}$ & $28.64 \mathrm{G}$ & $1.33 \mathrm{E}$ & $1.67 \mathrm{~F}$ & $83.62 \mathrm{~F}$ & $82.32 \mathrm{D}$ & $33.72 \mathrm{~F}$ & $32.29 \mathrm{G}$ \\
\hline 3 & $48.23 \mathrm{~F}$ & $48.94 \mathrm{~F}$ & $30.69 \mathrm{~F}$ & $30.60 \mathrm{~F}$ & $2.00 \mathrm{D}$ & $2.00 \mathrm{EP}$ & $84.44 \mathrm{~F}$ & $86.31 \mathrm{D}$ & $25.61 \mathrm{G}$ & $34.71 \mathrm{~F}$ \\
\hline 4 & $50.26 \mathrm{E}$ & $51.16 \mathrm{E}$ & $33.55 \mathrm{E}$ & $34.17 \mathrm{E}$ & $2.33 \mathrm{D}$ & $2.33 \mathrm{E}$ & $90.49 \mathrm{E}$ & $91.29 \mathrm{CD}$ & $40.59 \mathrm{E}$ & $39.33 \mathrm{E}$ \\
\hline 5 & $62.39 \mathrm{~B}$ & $63.66 \mathrm{~B}$ & $48.52 B$ & $43.03 \mathrm{~B}$ & $4.33 \mathrm{~B}$ & $5.00 \mathrm{~B}$ & $121.70 \mathrm{~B}$ & $85.12 \mathrm{D}$ & $55.49 \mathrm{~B}$ & $52.59 \mathrm{~B}$ \\
\hline 6 & $53.87 \mathrm{D}$ & $54.50 \mathrm{D}$ & $36.57 \mathrm{D}$ & $38.33 \mathrm{D}$ & $3.00 \mathrm{C}$ & $3.00 \mathrm{D}$ & $101.90 \mathrm{D}$ & $10.00 \mathrm{BC}$ & $42.60 \mathrm{D}$ & $44.38 \mathrm{D}$ \\
\hline 7 & $57.56 \mathrm{C}$ & $58.34 \mathrm{C}$ & $38.37 \mathrm{C}$ & $40.02 \mathrm{C}$ & 4.00B & $4.00 \mathrm{C}$ & $109.00 \mathrm{C}$ & $108.21 \mathrm{~B}$ & $49.06 \mathrm{C}$ & $49.07 \mathrm{C}$ \\
\hline 8 & $67.21 \mathrm{~A}$ & $66.53 \mathrm{~A}$ & $50.00 \mathrm{~A}$ & $47.36 \mathrm{~A}$ & $5.00 \mathrm{~A}$ & $6.00 \mathrm{~A}$ & $126.58 \mathrm{~A}$ & $125.76 \mathrm{~A}$ & $57.95 \mathrm{~A}$ & $57.81 \mathrm{~A}$ \\
\hline
\end{tabular}

Nutritional status (leafphotosynthetic pigments and mineral composition).

Leaf N, P, K, Ca, Mg, Fe, Mn, Zn and photosynthetic pigments (chlorophyll $\mathrm{a}, \mathrm{b}$ and carotenoids) contents were determined as indicators of nutritional status of guava transplants in response to different bio-fertilizer treatments. Data obtained are presented in Tables 3 and 4.

As shown in Tables 3 and 4 leaf macro and micro elements content $(\mathrm{N}, \mathrm{P}, \mathrm{K}$, $\mathrm{Ca}, \mathrm{Mg} \%, \mathrm{Fe}, \mathrm{Mn}$, and $\mathrm{Zn} \mathrm{ppm}$ ) and leaf photosynthetic pigments were increased significantly by all bio-fertilizers treatments as compared to control. Such trend was true during the both seasons of study. Anyhow, foliar spray of diluted Biomagic $\left(7.5 \mathrm{~g} / \mathrm{L}\right.$ water) at the rate of $50 \mathrm{~cm}^{3} /$ plant plus soil application of Kotengin at $20 \mathrm{~g} /$ plant + one liter Biovit $+\mathrm{K}_{2} \mathrm{SO}_{4}$ at $20 \mathrm{~g} /$ plant $\left(8^{\text {th }}\right.$ treatment $)$ was the most effective and exhibited statistically the highest leaf macro and micro nutrient elements content during both seasons. On the other hand, foliar spray of diluted Novatrene solution $(1.0: 150 \mathrm{v}: \mathrm{v})$ at the rate of $50 \mathrm{~cm}^{3} /$ plant plus soil application of Kotengin at $20 \mathrm{~g} /$ plant + phosphorine at $40 \mathrm{~g} /$ plant + Rhizobacterin at $40 \mathrm{~g} /$ plant $+\mathrm{K}_{2} \mathrm{SO}_{4}$ at $20 \mathrm{~g} /$ plant $\left(5^{\text {th }}\right.$ treatment $)$ ranked statistically $2^{\text {nd }}$. 
This result goes in line with Abd El-Migeed et al. (2007) on Washington navel orange. Moreover, findings of Osman et al. (2010) on two olive cultivars were in partial agreement with the present results in this respect regarding the simulative effect of some bio fertilizers.

The obtained results regarding leaf macro and micro nutrient contents of fruit trees were supported by the findings of Omar (2006) who reported that, olive transplants which received $\mathrm{N}$ as basal dressing led to increase leaf $\mathrm{N}$, $\mathrm{Ca}, \mathrm{Mg}$ and $\mathrm{Fe}$ content. El - Geuoshy (2011) on sweet orange trees found that, trees which were fertilized with the highest level of NPK soil application combined with bio - fertilizers significantly showed the highest values of leaf mineral contents ( $\mathrm{N}, \mathrm{P}, \mathrm{K}, \mathrm{Ca}, \mathrm{Mg}, \mathrm{Fe}, \mathrm{Zn}$ and $\mathrm{Mn}$ ). Bakry (2007) and Bakry et al. (2013) showed that, sweet orange leaves contained more N, P and $\mathrm{K}$ as a result of bio - fertilizers soil applications which encourage the leaves to gain more chlorophyll and more dry matter. Also, these results are in harmony with those found by Mohamed et al. (2010), Fawzi et al. (2010) and Abdou (2010) reported that, the highest leaf pigments content was obtained by bio-fertilizer stimulants of "Le- Conte" pear trees.

TABLE 3. Effect of mineral NPK fertilizers and their combinations with some bio fertilizers soil applied on leaf macro nutrient elements contents of guava transplants during 2011 \& 2012 seasons.

\begin{tabular}{|c|c|c|c|c|c|c|c|c|c|c|}
\hline \multirow{2}{*}{ Treat. } & \multicolumn{2}{|c|}{ Leaf $N \%$} & \multicolumn{2}{|c|}{ Leaf $P \%$} & \multicolumn{2}{|c|}{ Leaf $\mathrm{K} \%$} & \multicolumn{2}{|c|}{ Leaf Ca \% } & \multicolumn{2}{|c|}{ Leaf Mg \% } \\
\hline & $\begin{array}{c}1^{\text {st }} \\
\text { season }\end{array}$ & $\begin{array}{c}2^{n d} \\
\text { season } \\
\end{array}$ & $\begin{array}{c}1^{\text {st }} \\
\text { season }\end{array}$ & $\begin{array}{c}2^{\text {nd }} \\
\text { season }\end{array}$ & \begin{tabular}{c|}
$1^{s t}$ \\
season
\end{tabular} & $\begin{array}{c}2^{\text {nd }} \\
\text { season }\end{array}$ & $\begin{array}{c}1^{\text {st }} \\
\text { season }\end{array}$ & $\begin{array}{c}2^{n d} \\
\text { season }\end{array}$ & $\begin{array}{c}1^{s t} \\
\text { season } \\
\end{array}$ & $\begin{array}{c}2^{\text {nd }} \\
\text { season }\end{array}$ \\
\hline $\begin{array}{c}\mathrm{T} 1 \\
\text { (Control) } \\
\end{array}$ & $1.60 \mathrm{G}$ & $1.60 \mathrm{G}$ & $0.116 \mathrm{E}$ & $0.130 \mathrm{D}$ & $1.41 \mathrm{E}$ & $1.42 \mathrm{C}$ & $1.50 \mathrm{E}$ & $1.53 \mathrm{G}$ & $0.433 \mathrm{E}$ & $0.477 \mathrm{D}$ \\
\hline $\mathrm{T} 2$ & $1.73 \mathrm{~F}$ & $1.75 \mathrm{~F}$ & $0.150 \mathrm{D}$ & $0.153 \mathrm{C}$ & $1.45 \mathrm{E}$ & $1.45 \mathrm{C}$ & $1.56 \mathrm{E}$ & $1.55 \mathrm{G}$ & $0.493 \mathrm{D}$ & $0.520 \mathrm{D}$ \\
\hline $\mathrm{T} 3$ & $2.12 \mathrm{E}$ & $2.20 \mathrm{D}$ & $0.157 \mathrm{D}$ & $0.180 \mathrm{~B}$ & $1.65 \mathrm{D}$ & $1.69 \mathrm{~B}$ & $1.72 \mathrm{D}$ & $1.70 \mathrm{~F}$ & $0.610 \mathrm{C}$ & $0.660 \mathrm{C}$ \\
\hline $\mathrm{T} 4$ & $2.30 \mathrm{D}$ & $2.00 \mathrm{E}$ & $0.183 \mathrm{C}$ & $0.190 \mathrm{~B}$ & $1.66 \mathrm{D}$ & $1.69 \mathrm{~B}$ & $1.75 \mathrm{D}$ & $1.75 \mathrm{E}$ & 0717B & $0.740 \mathrm{BC}$ \\
\hline T5 & $2.80 \mathrm{~A}$ & $2.83 \mathrm{~B}$ & $0.273 \mathrm{~A}$ & $0.300 \mathrm{~A}$ & $2.98 \mathrm{~A}$ & $2.85 \mathrm{~A}$ & $2.07 \mathrm{~B}$ & $2.10 \mathrm{~B}$ & $0.820 \mathrm{~A}$ & $0.847 \mathrm{AB}$ \\
\hline T6 & $2.40 \mathrm{C}$ & $2.45 \mathrm{C}$ & $0.193 \mathrm{C}$ & $0.200 \mathrm{~B}$ & $1.67 \mathrm{D}$ & $1.68 \mathrm{~B}$ & $1.83 \mathrm{C}$ & $1.90 \mathrm{C}$ & $0.720 \mathrm{~B}$ & $0.747 \mathrm{BC}$ \\
\hline $\mathrm{T} 7$ & $2.48 \mathrm{~B}$ & $1.29 \mathrm{H}$ & $0.187 \mathrm{C}$ & $0.200 \mathrm{~B}$ & $1.75 \mathrm{C}$ & $1.68 \mathrm{~B}$ & $1.84 \mathrm{C}$ & $1.85 \mathrm{D}$ & $0.733 \mathrm{~B}$ & $0.673 \mathrm{C}$ \\
\hline $\mathrm{T} 8$ & $2.85 \mathrm{~A}$ & $2.95 \mathrm{~A}$ & $0.240 \mathrm{~B}$ & $0.310 \mathrm{~A}$ & $2.81 \mathrm{~B}$ & $2.85 \mathrm{~A}$ & $2.21 \mathrm{~A}$ & $2.17 \mathrm{~A}$ & $0.827 \mathrm{~A}$ & $0.863 \mathrm{~A}$ \\
\hline
\end{tabular}

Values within each column followed by the same letter/s are not significantly different at $5 \%$ level. 
TABLE 4. Effect of mineral NPK fertilizers and their combinations with some bio fertilizers soil applied on leaf micro nutrient elements and photosynthetic pigments contents of guava transplants during 2011 \& 2012 seasons.

\begin{tabular}{|c|c|c|c|c|c|c|c|c|c|c|c|c|}
\hline \multirow[t]{3}{*}{ Treat. } & \multicolumn{2}{|c|}{ Fe (ppm) } & \multicolumn{2}{|c|}{ Zn (ppm) } & \multicolumn{2}{|c|}{ Mn (ppm) } & \multicolumn{2}{|c|}{$\begin{array}{l}\text { Chlorophyll } \\
\text { (A) } \mathrm{mg} / \mathrm{g} \mathrm{f.} \mathrm{w}\end{array}$} & \multicolumn{2}{|c|}{$\begin{array}{l}\text { Chlorophyll } \\
\text { B) mg/g f. w }\end{array}$} & \multicolumn{2}{|c|}{$\begin{array}{c}\text { Carotene (mg } \\
\text { g f. w ) }\end{array}$} \\
\hline & $1^{\text {st }}$ & $2^{n d}$ & $\mathbf{1}^{s t}$ & $2^{n d}$ & $\mathbf{1}^{s t}$ & $2^{n d}$ & $\mathbf{1}^{s t}$ & $2^{n d}$ & $1^{s t}$ & $2^{n d}$ & $\mathbf{1}^{s t}$ & $2^{n d}$ \\
\hline & & & & & & & & & & & & SOn \\
\hline $\begin{array}{c}\mathrm{T} 1 \\
\text { (Control) }\end{array}$ & $136.3 \mathrm{G}$ & $138.7 \mathrm{G}$ & $47.67 \mathrm{E}$ & 59.67D & $72.50 \mathrm{E}$ & $73.00 \mathrm{E}$ & $4.57 \mathrm{H}$ & $4.65 \mathrm{H}$ & $1.82 \mathrm{~F}$ & $1.83 \mathrm{E}$ & $2.43 \mathrm{~F}$ & $2.48 \mathrm{C}$ \\
\hline $\mathrm{T} 2$ & $143.3 \mathrm{~F}$ & $144.7 \mathrm{~F}$ & $52.33 \mathrm{D}$ & $53.33 \mathrm{E}$ & $84.50 \mathrm{D}$ & $85.00 \mathrm{D}$ & $4.72 \mathrm{G}$ & $4.73 \mathrm{G}$ & $1.86 \mathrm{~F}$ & $1.87 \mathrm{E}$ & $2.48 \mathrm{~F}$ & $2.52 \mathrm{C}$ \\
\hline $\mathrm{T} 3$ & $147.3 \mathrm{E}$ & $150.3 \mathrm{E}$ & $57.67 \mathrm{C}$ & 59.33D & 86.00D & $86.00 \mathrm{D}$ & $4.85 \mathrm{~F}$ & $4.86 \mathrm{~F}$ & $1.92 \mathrm{E}$ & $1.95 \mathrm{D}$ & $2.58 \mathrm{E}$ & $2.60 \mathrm{BC}$ \\
\hline $\mathrm{T} 4$ & $152.0 \mathrm{D}$ & $154.7 \mathrm{D}$ & $65.00 \mathrm{~B}$ & $66.00 \mathrm{C}$ & $87.33 \mathrm{D}$ & $85.83 \mathrm{D}$ & $4.96 \mathrm{E}$ & $4.95 \mathrm{E}$ & $1.99 \mathrm{D}$ & $2.01 \mathrm{C}$ & $2.70 \mathrm{D}$ & $2.73 \mathrm{~B}$ \\
\hline T5 & $185.0 \mathrm{~B}$ & $188.0 \mathrm{~B}$ & $71.33 \mathrm{~A}$ & $77.00 \mathrm{~B}$ & $115.0 \mathrm{~B}$ & $113.5 \mathrm{~B}$ & $7.20 \mathrm{~B}$ & $7.26 \mathrm{~B}$ & $2.91 \mathrm{~B}$ & $2.93 \mathrm{~A}$ & $2.84 \mathrm{~B}$ & $3.85 \mathrm{~A}$ \\
\hline T6 & $162.7 \mathrm{C}$ & $162.7 \mathrm{C}$ & $63.33 \mathrm{~B}$ & $66.67 \mathrm{C}$ & $95.00 \mathrm{C}$ & $97.50 \mathrm{C}$ & $6.12 \mathrm{D}$ & $6.21 \mathrm{D}$ & $2.17 \mathrm{C}$ & $2.25 \mathrm{~B}$ & $2.73 \mathrm{CD}$ & $2.77 \mathrm{~B}$ \\
\hline $\mathrm{T} 7$ & $165.0 \mathrm{C}$ & $166.0 \mathrm{C}$ & $65.33 \mathrm{~B}$ & $68.00 \mathrm{C}$ & $96.00 \mathrm{C}$ & $82.50 \mathrm{D}$ & $6.35 \mathrm{C}$ & $6.40 \mathrm{C}$ & $2.20 \mathrm{C}$ & $2.25 \mathrm{~B}$ & $2.79 \mathrm{C}$ & $2.79 \mathrm{~B}$ \\
\hline $\mathrm{T} 8$ & $197.7 \mathrm{~A}$ & $202.0 \mathrm{~A}$ & $73.67 \mathrm{~A}$ & $80.00 \mathrm{~A}$ & $122.5 \mathrm{~A}$ & $123.0 \mathrm{~A}$ & $7.42 \mathrm{~A}$ & $7.47 \mathrm{~A}$ & $2.98 \mathrm{~A}$ & $2.99 \mathrm{~A}$ & $3.92 \mathrm{~A}$ & $3.93 \mathrm{~A}$ \\
\hline
\end{tabular}

\section{References}

A.O.A.C. (1990) "Official Method of Analysis", $10^{\text {th }}$ ed., Association of Official Analy tical Chemists, Inc USA.

Abd El-Migeed, M.M., Saleh, M.M. and Mostafa, E.A. (2007) The beneficial effect of minimizing mineral nitrogen fertilization on Washington navel orange trees by using organic and biofertilizers. World J. Agric. Sci., IDOSI Publications, Faisal abad, Pakistan, 3 (1), 80-85, 22 ref.

Abdou, N.A. (2010) Response of le-Conte pear trees to organic and some bio-fertilizers in comparison with chemical fertilizer. M.Sc. Thesis, Fac. Agric., Cairo Univ., Egypt.

Abd-Rabou, F.A. (2006) Effect of microbien, phosphorine and effective microorganisms (EM) as bio-stimulants on growth of avocado and mango seedlings. Egypt. J. Appl. Sci., 21 (6B), 673-693.

Ahmed, F.F., El-Dawwey, G.M. and Papasopoulos, A.P. (1999) Efficiency of phosphorine (as a source of phosphate solubilizing bacteria) in enhancing growth and $\mathrm{P}$ nutrition of chemlali olive seedlings. International Sym. on growing media and hydroponics, Windsor, Ontario, Canada,19-26 May,Vol. II. Acta Hort., 481,701-705. 
Bakry, Kh. A. (2007) Response of Jafa orange trees to spray with yeast extract and promalin. Egypt. J. Appl. Sci., 22 (10A), 195-210.

Bakry, Kh. A., Khamis, M.A., Sharaf, M.M., Ebrahim, H.K. and Yassin, H.I. (2013) Response of Washington navel orange trees to foliar spray with some bio and mineral fertilizers. The first international conf. for economic development in African and Arab region, 23-24 April, Ismailia, Egypt.

Chandler, W. H. (1958) Evergreen Orchards, Henry Kimpton, London, p. 452.

Chokha, S., Saxena, S.K., Gaswami, A.M., Sharma, R.R. and Singh, C. (2000) Effect of fertilizers on growth, yield and quality on sweet orange (Citrus sinensis) $\mathrm{Cv}$. Mosambi. Indian J. Hort. 57 (2), 114-117.

Duncan, D. B. (1955) Multiple range and multiple F. tests. Biometrics, 11, 1-42.

El-Geuoshy, S.F. (2011) Physiological and anatomical studies on some factors affecting productivity and nutritional status of navel orange. Ph.D. Thesis., Fac. of Agric. Benha Univ., Egypt.

Fawzi, F. M., A. D. Elham and E. A. Kandil (2010) Effect of organic and bio-fertilizers and magnesium sulphate on growth yield, chemical composition and fruit quality of "Le-Conte" Pear trees. Nature and Sci. 8 (12),273-280.

Godeston, J. and Chanin, M. (1946) The guava fruit containing a new vitamin C. Rev. Inst. Def. Cafe. Costa Rica: Hort. Abst. 25, 328 b.

Haggag, L.F. and Azzazy, M. A. (1996) Evaluation of Microbien as a multistrains biofertilizers for producing of improved mango seedlings with appropriate vigor for grafting in shorter time. Annals of Agric. Sci. Cairo, 41 (1), 321-331.

Ishac, Y.Z. (1989) Inoculation with associative N2-fixers Egypt. Nitrogen fixation with non-legumes, Kluwer Academic Publishers, pp. 241-246.

Israelsen, O.W. and Hansen, V.E. (1962) Irrigation principles and practices. John Wiley and sons, 1nc. New York.

Izquierdo, I., Lescaille, M., Sandrino, B., Garcia, M.J., Canizares. E., Azcuy, J., Rodriguez, M.E. and Gallardo, J.F. (1993) Effects of biofertilizers combinations on the availability of soil NPK to Citrus volkameriana seedlings. Actas del 12 Congreso latino americano de la Ciencia del Suelo, Salamanca, Sevilla (Espania) la 26 de Septiembre de, 711-719.

Jackson, M.L. (1967) "Soil Chemical Analysis" Hall. of India private, New Delhi, India.

Khamis, M.A., Sharaf, M.M., Bakry, Kh. A., Ebrahim, H.K. and Yassin, H.I. (2012) Effect of some bio and mineral fertilizers on growth, productivity, fruit quality and nutritional status of Washington navel orange trees. Egypt. J. Appl. Sci. 4.

Mohamed, S.M., Fayed, T.A., Ismail, A.F. and Abdou, N.A. (2010) Growth, nutrient status and yield of le-Conte pear trees as influenced by some organic and biofertilizer rates compared with chemical fertilizer. Bull. Fac. Agric. Cairo Univ. 61, 17-32.

Egypt. J. Hort. Vol. 42, No.1 (2015) 
Omar, Th. M. (2006) Effect of some biological treatments on olive seedlings. Ph. D. Thesis, Fac. Agric., Benha Univ.

Osman, S.M., Khamis, M.A. and Thorya, A.M. (2010) Effect of mineral and Bio-NPK soil application on vegetative growth, flowering, fruiting and leaf chemical composition of young olive trees. Res. J.Agric. Biological Sci., 6 (1), 54-63.

Saber, S. M. (1993) The use of multi-strain bio-fertilizer in agriculture. Theory and practice. Proc. Sixth International Symposium on Nitrogen Fixation with Nonlegumes, Ismailia, Egypt, p.61.

Shaban, A.E.A. and Mohsen, A.T. (2009) Response of citrus rootstock and transplants to bio - fertilizers. J. of Hort. Sci. \& Ornamental Plants, 1 (2), 39 - 48.

Snedecor, G.W. and Cochran, W.G. (1977) "Statistical Methods", $8^{\text {th }}$ ed, Iowa State Univ. Press.

Soliman, M.G. (2001) Response of banana and guava plants to some biological and mineral fertilizers. M.Sc. Thesis, Fac. of Agric. Alex. Univ., Egypt.

Statistics of Ministry of Agriculture, A.R.E. (2012) Agricultural cltuensus of 2012 year, Ministry of Agriculture A.R.E.

(Received 8/9/2014;

accepted 8/1/2015) 


\section{استجابة شتلات الجوافة لتسميذ الارضى والرش الورقى بيعض منشطات النمو}

محمد عبد الوهاب خميس ، محمد محمد شرف ، خالد على بكرى و عبد المعطى

سالم عبد المعطى الوهاب

قسم البساتين -كلية الزر اعة - جامعة بنها - بنها -مصر.

فى هذا البحث نم اختبار بعض الاسمدة الحيوية من حيث تاثير ها على النمو و الحالة

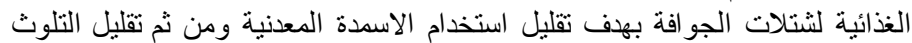



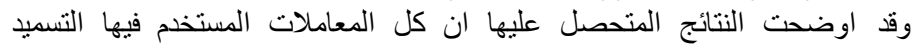

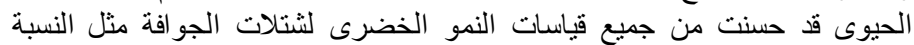

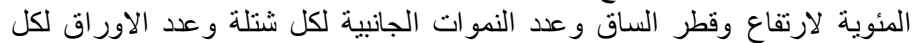

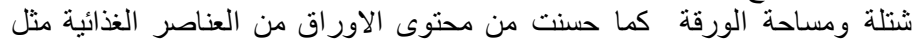

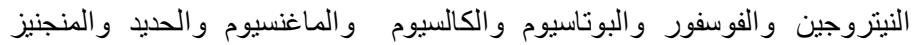

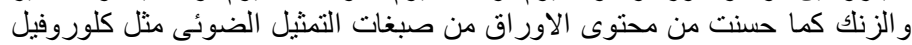

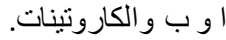

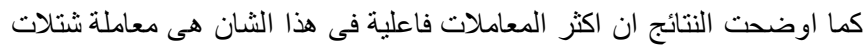

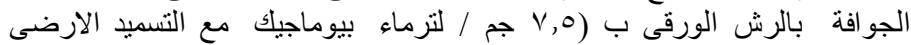



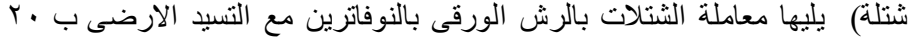

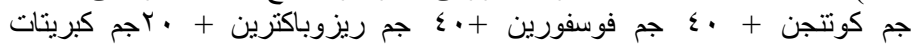
بوتاسيوم لكل شنتلة) 